\title{
Comparative Analysis of Disaster Management Between Indonesia and Japan from Regulatory and Institutional Aspects
}

\author{
Titie Yustisia Lestari ${ }^{1 *}$, Rahmia Rachman ${ }^{1}$, and Adiesty Septhiany Prihatiningsih \\ Syamsuddin ${ }^{1}$ \\ ${ }^{1}$ Legal Science, Law Faculty, Tadulako University, Palu Central Sulawesi
}

\begin{abstract}
The Indonesian government still faces several obstacles in handling disasters. One classic obstacle is the implementation of disaster management regulation that is not yet optimal. Japan's regulation on disaster management has been in existence since 1941, indicating that the readiness of the Government of Japan in tackling disasters has begun long before the Indonesian Government enacts Act No. 24 of 2007. This study uses a comparative analysis research method by comparing the regulation related to disaster prevention in Japan and Indonesia. In addition, the author also tries to make comparisons between disaster management agencies that exist in Japan and Indonesia. The results show that the readiness of the Government of Indonesia related to the regulation and institutional of disaster management has undergone significant improvement since the handling of the earthquake and tsunami that hit Aceh and Nias in 2004 ago. There are many disaster management differences between Indonesia and Japan. One of the significant ones is the alertness of the Japanese government in conducting preventive prevention through the socialization of disaster reduction that involves all elements of society.
\end{abstract}

\section{Introduction}

Indonesia and Japan as a disaster-prone country are required to have excellent disaster management. Unlike Indonesia, Japan is one of the countries that often experience natural disasters. One of the natural disasters that hit Japan in the last 10 years was the Great East Japan Earthquake that shook Japan in May 2011 which resulted in approximately 21,839 fatalities. The disaster was followed by a tsunami which then caused considerable damage to one of the nuclear reactors in Japan, the Fukushima nuclear reactor which is still in the recovery stage. Japan is located in the Circum Pacific Mobile Belt where seismic and volcanic activities occur constantly. Although the country covers only $0.25 \%$ of the land area on the planet.

In addition, because of geographical, topographical, and meteorological conditions, the country is subject to frequent natural disasters such as typhoons, torrential rains, and heavy snowfalls as well as earthquakes and tsunamis. Apart from the many natural disasters that

${ }^{*}$ Corresponding author : titieyustisia@hotmail.com 
befell Japan, Japan is known as one of the countries with excellent disaster management, this can be seen from the readiness of the government in handling disasters that arise both on a small and large scale.

The history of disaster management legislation in Japan began in 1940, namely the promulgation of The Flood Control Act which was followed by The Disaster Relief Act in the same year. Whereas Indonesia only has special regulations governing disasters in 2007 with the promulgation of Act No. 24 of 2007 [1] concerning Disaster Management in response to the tsunami that struck Aceh and Nias. However, implementation in the field is still in the recovery stage. Japan is located in the Circum Pacific Mobile Belt where seismic and volcanic activities occur constantly. Although the country covers only $0.25 \%$ of the land area on the planet.

In addition, because of geographical, topographical, and meteorological conditions, the country is subject to frequent natural disasters such as typhoons, torrential rains, and heavy snowfalls as well as earthquakes and tsunamis. Apart from the many natural disasters that befell Japan, Japan is known as one of the countries with excellent disaster management, this can be seen from the readiness of the government in handling disasters that arise both on a small and large scale.

The history of disaster management legislation in Japan began in 1940, namely the promulgation of The Flood Control Act which was followed by The Disaster Relief Act in the same year. Whereas Indonesia only has special regulations governing disasters in 2007 with the promulgation of Act No. 24 of 2007 [1] concerning Disaster Management in response to the tsunami that struck Aceh and Nias. However, implementation in the field is still experiencing many obstacles, one of which is the awareness and knowledge of the community related to disaster management.

\subsection{Problem}

Based on the background, the following problems can be identified: how is the comparison of disaster management between Indonesia and Japan in terms of legislation and institutions?

\subsection{Research Method}

This research is a normative legal ${ }^{2}$ research by examining regulation and institution regarding disaster management from both countries which are Indonesia and Japan. The data that were used to compare both subjects are the laws that are concerned about disaster management. The implementation of this research was carried out using the comparative approach method. The analysis is done by comparing various formulations of rules that govern the same object.

\section{Discussion}

Act No. 24 of 2007 concerning Disaster Management states that disasters are events or series of events that disrupt people's lives and livelihoods caused by natural factors and/or nonnatural factors and human factors resulting in human casualties, environmental damage and property losses and psychological impact [2]. The birth of the Disaster Management Law followed by the enactment of several implementing regulations such as Government Regulation Number 21 of 2008 [3] concerning Disaster Management, Government Regulation Number 22 of 2008 [4] concerning Funding and Management of Disaster Relief, Government Regulation Number 23 of 2008 concerning the Role of International Institutions and Non-Governmental Foreign Institutions in Disaster Management, Presidential Regulation Number 8 of 2008 [5] concerning the National Disaster Management Agency 
has changed the disaster management paradigm in Indonesia compared to the period before the Disaster Management Law. The paradigm, which is disaster management not only emphasizes the aspects of emergency response, but also emphasizes the overall aspects of disaster management which include pre-disaster, during disasters (emergency response), and after a disaster.

\subsection{Implementation of Disaster Management Systems in Indonesia}

Act No. 24 of 2007 concerning Disaster Management is promulgated as a way to overcome the weaknesses of inter-sectoral coordination and provide a strong legal basis in handling disaster problems. With the promulgation of Act Number 24 of 2007 concerning disaster Management, on April 26, 2007, it was hoped that disaster management would be systematic, integrated and coordinated.

Act Number 24 of 2007 concerning Disaster Management consists of 13 Chapters and 85 Articles, with the main material included, among others, concerning a) the implementation of disaster management is the responsibility and authority of the government and regional government; b) that the emergency response phase is carried out entirely by the National Disaster Management Agency and the Regional Disaster Management Agency; c) fulfillment of community rights in the disaster management process; d) opportunities for business institutions and international institutions to assist disaster management activities; e) disaster management is carried out during pre-disaster, during disaster and post-disaster; f) funds are provided from the State Budget and Regional Budget and ready-to-use funds are also provided for which the accountability mechanism is carried out specifically; g) supervision is carried out by the government, regional government and the community; h) and finally the inclusion of criminal provisions.

The criteria for disaster status and level are determined by the central government based on the number of victims, property losses, damage to facilities and infrastructure, wide coverage affected by the disaster and socio-economic impacts arising. This criterion will determine whether an event is called a disaster or not ${ }^{+}$[2].

Act No. 24 of 2007 concerning institutional disaster management in disaster management is carried out by the National Disaster Management Agency established by the central government with presidential regulations. While in the regional area, the Regional Disaster Management Agency was established with regional regulations ${ }^{\text {[2] }}$. The Regional Disaster Management Agency is divided into two at the provincial and district/city levels. In Act Number 24 of 2007 concerning Disaster Management, it is regulated on the matter of the establishment of the two bodies above, including the authority, function, duties, and procedures for selecting the Steering Committees. It should also be noted that although Regional Disaster Management Agency was formed by the regional government, in its formation it had to wait for National Disaster Management Agency to be formed and guidelines for the establishment of Regional Disaster Management Agency prepared by National Disaster Management Agency.

At the time of the emergency response, these two agencies were fully carried out, so that it was regulated in Act Number 24 of 2007 concerning Disaster Management regarding the ease of access to various resources spread across various sectors. The ease of access includes also in terms of logistics deployment, immigration, excise and quarantine, provision of goods and services, financial management and accountability and even command to govern sectors/institutions. This is a manifestation of the desire to make disaster management activities systematic, integrated and coordinated.

Article 12 of Act Number 24 of 2007 states the duties of the National Disaster Management Agency namely: 
1. Providing guidance and direction to disaster management efforts that cover disaster prevention, handling emergency response, rehabilitation and reconstruction fairly and equally;

2. Establishing standardization and needs for the implementation of disaster management based on legislation;

3. Deliver information on disaster management activities to the community

4. Reporting the implementation of disaster management to the President once a month in normal conditions and at all times in disaster emergency conditions;

5. Use and account for national and international donations/assistance;

6. Account for the use of the budget received from the State Budget;

7. Carry out other obligations in accordance with the laws and regulations;

8. Develop guidelines for the establishment of the Regional Disaster Management Agency.

The outline of the scope of implementing disaster management becomes:

1. Disaster management covers pre-disaster, emergency response, and post-disaster;

2. Prioritize preventive efforts during pre-disaster;

3. Implementation of rehabilitation and reconstruction efforts in post-disaster.

The National Disaster Management Agency is a ministerial non-departmental institution that is directly responsible to the President in dealing with disaster management. National Disaster Management Agency then supervises the Regional Disaster Management Agency which is an extension of the National Disaster Management Agency in districts and cities throughout Indonesia. National Disaster Management Agency is specifically regulated in Presidential Regulation Number 8 of 2008 concerning the National Disaster Management Agency. The organizational structure of the National Disaster Management Agency consists of the Head, the Guidance Committee for Disaster Management and the Committees of Disaster Management Executors.

Members of the National Disaster Management Agency steering committee consist of the chairperson held by the Chairman of National Disaster Management Agency and 19 members consisting of 10 officials from relevant government institutions and 9 members of the professional community ${ }^{6}$ [5].

\subsection{Implementation of Disaster Management Systems in Japan}

Japan's legal instrument for the reduction of risk from natural disaster consists of the Disaster Countermeasure Basic Act [6] and another legal instrument which covers many types of a disaster such as an earthquake, tsunami, erosion, building standard, city planning, land use, road, landslide, typhoon, steep slope collapse, active volcanoes, fire, flood, river and forest and etc. Japan has a long history of disaster management laws and systems since 1945. The unique thing regarding the journey of disaster management laws in Japan that the enactment of an Act was triggered by a disaster that happens earlier. There are 42 in a total of laws that were enacted in Japan regarding disaster management.

Disaster Countermeasures Basic Act is a national disaster management law of Japan which consist definition of the 1) philosophy and the responsibility for disaster management; 2) disaster management administration; 3) planning system management; 4) promotion of disaster countermeasure; 5) protection of affected people and their livelihood;

6)financial measures;7) state of disaster emergency. Disaster Countermeasure Basic Act is a legal foundation for the establishment of the Central Disaster Management Council who is one of the councils that deals with crucial policies of the Cabinet and is established in the Cabinet Office [7], [8].

Central Disaster Management Council prepared a Basic Disaster Management Plan which is a comprehensive and long-term disaster management plan forming a foundation for 
the Disaster Management Operations Plan and Local Disaster Management Plan. Disaster Management Operation Plan by each designated government organization and designated public corporation; and the Local Disaster Management Plan by each prefectural

and municipal disaster council. These plans together establish a comprehensive disaster management system in Japan which deals with all the phases of disaster management: prevention; mitigation and preparedness; emergency response; and, recovery and rehabilitation.

Central Disaster Management Council comprised of the Prime Minister and Minister of State for Disaster Management and all members of The Cabinet as The Chair. Heads of Designated Public Corporation and experts on disaster-related issues acting as a member of the council. Designated Public Corporation consists of 66 organizations including independent administrative agencies, Bank of Japan, Japanese Red Cross Society, Japan Broadcasting Corporation (NHK), Nippon Telegraph and Telephone Corporation (NTT), electric and gas companies ${ }^{8}$ [7].

At the prefectural level, under a Local Disaster Management Plan which is prepared by a Prefectural Disaster Management Council, governor, prefectural government, designated local government organizations, designated local public corporations and other concerned parties carry out measures for disaster management At the municipal level, under a Local Disaster Management Plan which is prepared by the Municipal Disaster Management Council, the head of city/town/village and municipal government implement the measures in cooperation with the police, fire departments, community groups, schools, and other concerned parties.

Details of measures for different types of disaster, as well as competence and duties of institutions/stakeholders in dealing with disasters, are prescribed by each specialized laws (e.g. Flood Control Act, Landslide Prevention Act, Act on Special Measures for Active Volcanoes, and Act on Special Measures for Disaster Prevention in Typhoon-prone Areas) whereas the general countermeasures, as well as general competence and duties, are provided for by the Disaster Countermeasures Basic Act.

There are four main aspects of the Disaster Countermeasure Basic Act regarding disaster management which are disaster response, disaster preparedness, disaster mitigation and prevention, and disaster risk reduction. Although disaster risk reduction is not explicitly stated in the Act, the term of disaster prevention and preparedness is considered as parallel to disaster risk reduction.

Disaster Countermeasures Basic Act allocated responsibilities in many parties such as the prime minister, various ministries, local government, and communities. At the level of the prime minister, most of the responsibilities are to designated administrative organs related to disaster management, policy setting of disaster management, to establish headquarter for major disaster control, to receive a report from the Central Disaster Prevention Council, declare a state of emergency, to receive reports from the governor of the disaster-stricken prefecture.

Community responsibility also stated in the Act at Article 7 provides for the responsibilities of residents and others at prefectural, municipal and community levels. Civil society actors explicitly mentioned in the Article are public organizations in the areas of local public authorities and residents. The said public organizations are "obligated, by law or under an appropriate area disaster prevention plan, to fulfil their responsibilities in good faith" ${ }^{\text {10. }}$.

Residents are to play such a role as "to contribute toward the cause of disaster prevention by taking their own measures to prepare for a disaster and by participating in voluntary disaster prevention groups etc." ". The role of civil society is also prescribed by the Basic Framework for Promoting a Nationwide Movement for Disaster Reduction which was decided and published by the Central Disaster Management Council in 2006 in order to "promote a nationwide movement where individuals, families, communities, corporations 
and other various groups and entities participate in continuous activities and investments for mitigating disaster damage" ${ }^{\prime 2}$.

\section{Conclusion}

Disaster management arrangements between Indonesia and Japan have many differences both in terms of rules and institutions. Disaster management in Indonesia is handled by the National Disaster Management Agency which oversees the Regional Disaster Management Agency. The involvement of other institutions in managing disasters is also regulated in the law, but it is not explained in more detail about the roles and workflows of these institutions. Therefore when disasters occur there is often overlapping of coordination between institutions. This then becomes one of the problems when large-scale disasters occur. Due to a lack of coordination, disaster management is often less than optimal and inefficient. The organizational structure of the National Disaster Management Agency consists of the Chairperson, the Steering Committee which consists of Government Officials from other institutions or ministries, and the Executive Committee whom responsible for the president. Whereas in Japan disaster management involves many parties, ranging from the Prime Minister who is the chairman of the Disaster Management Council which is assisted by a special ministry that handles disaster management, relevant ministries, public corporations, and experts.

The regulation regarding disaster management in Japan is more diverse and specific in regulating the types of disasters and their handling. So that when a disaster occurs, the protocol regarding disaster management is very clear and there is no overlapping of coordination between institutions that play a role in handling disasters. Furthermore, community empowerment in helping to deal with disasters is also better when compared to Indonesia. The community in Japan actively participates in assisting the Local Government in organizing disaster management. This is of course inversely proportional to the situation in Indonesia, where people tend to be passive when disasters occur

The formation of regulations governing disaster management in Japan involves all parties from the national level to the regional or district level including the community so that the process of forming legislation related to disaster management does not run slowly. It is possible to develop a comprehensive disaster management regulation that is capable of covering the needs of each community. Whereas the formation of rules in Indonesia is still carried out by the National Disaster Management Agency, the executive body and the state legislature which requires a very long time to produce regulation. At the regional level, regulations are issued by the Regional Disaster Management Agency and executive and legislative institutions in the regions.

The Disaster Management Law in Japan has clearly stated the involvement of other parties other than the government organs which in this case are the National Army, StateOwned Enterprises, Non-Government Organizations, and other parties which also cover their respective roles party. Whereas in Law No. 24 of 2007, the involvement of other parties was only mentioned explicitly and not in detail. So that there is often overlapping coordination between each party when a disaster occurs. For example, the role of the Indonesian National Army is not regulated in the event of a natural disaster. Despite the fact, the Indonesian National Army has a very central role in addition to the National Search and Rescue Agency and the National Disaster Management Agency when a disaster occurs.

The derivative legal product of Law No. 24 of 2007 which is still in the process also hampers the handling of disasters in the regions, for example, the determination of the status of the disaster mentioned in Law No. 24 of 2007 which is determined by the president based on certain considerations which until now the Government Regulations supporting the 
determination of the status of the disaster have not yet been completed. This is very important because it is closely related to the implementation of costs in the event of a disaster.

The formation of disaster units is carried out until the smallest unit consisting of people living in the prefecture or district allows the community to be actively involved in predisaster, disaster, and post-disaster periods. So when a disaster occurs, disaster management units consisting of the community can immediately do the things that are necessary when a disaster occurs before assistance arrives. The Japanese government is also active in conducting disaster mitigation and disaster socialization involving all parties including the community. Disaster education is also a concern in the education curriculum in Japan so that every member of the community including children has fundamental knowledge about first aid when a disaster occurs. Pre-disaster activities are also often carried out, for example launching the National Disaster Prevention Day on September 1.

In Indonesia, community involvement is still very minimal and tends to be passive when disasters occur. Lack of awareness and knowledge of the community about disaster mitigation causes no coordination when disasters occur so that it is vulnerable to causing chaos in the event of a disaster. Disaster management in Indonesia is still focused on when disasters occur and post-disaster, while activities in the pre-disaster period have not yet become full attention.

\section{References}

1. S. Soekanto and S. Mamudji, Penelitian hukum normatif: Suatu tinjauan singkat. RajaGrafindo Persada, (2001).

2. Act Number 24 of 2007 concerning Disaster Management. (2018).

3. Government Regulation Number 21 of 2008 concerning Implementation of Disaster Management. (2008).

4. Government Regulation Number 22 of 2008 concerning Funding and Management of Disaster Relief.(2008).

5. Presidential Regulation Number 8 of 2008 concerning the National Disaster Management Agency. (2008).

6. Background Report, Law and Regulation for the Reduction of Risk from Natural Disasters in Japan, A National Law Desk Survey October. (2012).

7. Disaster Countermeasure Basic Act. (1961).

8. Director-General For Disaster Management Cabinet Office, Government of Japan, Disaster Management In Japan, A National Law Desk Survey. (2015). 